\title{
Looking under Kachru's (1982, 1985) Three Circles Model of World Englishes: The Hidden Reality and Current Challenges ${ }^{1}$
}

\section{Um olhar subjacente ao modelo de Kachru (1982, 1985) de três círculos de "World Englishes": A realidade escondida e desafios atuais}

John Robert Schmitz*

Universidade Estadual de Campinas

Campinas - São Paulo / Brazil

\begin{abstract}
This paper examines the pioneering model of World Englishes formulated by Kachru in the early 1980s that allocates the presence of English into three concentric circles: first of all, the inner circle (Great Britain, the USA) where the language functions as an L1 (or native language); secondly, the outer circle (India, Nigeria) where the language was forced upon the subjugated people by Britain; thirdly, the expanding circle (China, Brazil) where English is studied as a foreign language. Researchers in the area of language studies tend to put too much store in Kachru's model expecting it to expose the different circles: (i) the proficiency level of the speakers, (ii) the variation that exists in the different dialects of the language, and (iii) how the many users appropriate the language to perform their daily routine. Pung (2009) suggests "going beyond" the three circle model with his proposal of a Conical Model of English (CME), while Park and Wee (2009, p.402) state that models have no "magical efficacy in challenging dominant ideologies of English" and that change in the world is not brought about by models but my people. Based on Park and Lee's caution with regard to models, and in lieu of Pung's "going beyond" the well-known Kachruvian model, the thrust of this article is to look specifically under the inner circle, that is, the supposed "native speaker domain". It will be argued in this paper that the circles
\end{abstract}

* john.schmitz@uol.com.br

${ }^{1}$ I am grateful to the anonymous readers of this article for their comments and suggestions. Special thanks to my proof reader for his careful reading. The paper, as it stands, is my responsibility. 
function as a palimpsest erasing and ignoring what happened in the past linguistically, historically and culturally before the appearance of English in the spaces that the language occupies at the present time in the inner, outer, and expanding circles. An examination of days gone-by, with a focus on Kachru's inner circle, can present a mirror to examine: (i) bilingual (multilingual) biases, (ii) migration of peoples and treatment of immigrants, (iii) respect (or lack of) for the linguistic and cultural rights of minorities, and (iv) the hegemony of English in relation to other languages - issues that concern us today and will continue to do so in the coming years.

KEYWORDS: three circles model, immigration, multiculturalism, ethnic diversity, prejudice, monolingual mindset.

RESUMO: Este artigo tem a finalidade de examinar o modelo pioneiro de "World Englishes" proposto por Kachru a partir da década de 80 do século passado que aloca a presença de inglês no mundo em três círculos concêntricos: em primeiro lugar, o círculo interno (Reino Unido, Estados Unidos) onde a língua inglesa funciona como uma L1 (ou língua nativa); em segundo lugar, no círculo externo (Índia, Nigéria) onde o idioma foi impingido aos povos subjugados pelo poderio britânico; e em terceiro lugar, no círculo em expansão (China, Brazil) onde o inglês é estudado como língua estrangeira. Os pesquisadores no campo dos estudos da linguagem tendem a exigir demais do modelo de Kachru esperando que desvende nos diferentes círculos: (i) o nível de proficiência dos falantes, (ii) a variação que existe entre as diferentes variedades do idioma e (iii) como os diferentes usuários se apropriam do inglês para o desempenho de suas atividades diárias. Pung (2009) sugere, por um lado, de "ir além" do modelo de três círculos com base na sua proposta de um Modelo Cônico de Inglês (Conical Model of English (CME) enquanto, por outro lado, Park e Wee (2009) afirmam que os modelos não oferecem "uma eficiência mágica no questionamento das ideologias dominantes do Inglês" (tradução minha) e acrescentam que são os seres humanos que realizam mudanças no mundo e não os modelos. Com base na cautela por parte de Park e Lee com respeito à problemática de modelos e ao invés da postura de Pung de "ir além" do conhecido modelo idealizado por Kachru, a finalidade deste trabalho é a de olhar por baixo do referido modelo, especificamente o círculo interno, isto é, o suposto "domínio do falante nativo". Argumentamos nesta reflexão que os círculos funcionam como um palimpsesto que apaga e ignora o que sucedera no passado, linguística, histórica e culturalmente, antes do surgimento do Inglês que esse idioma ocupa atualmente nos círculos interno, externo e em expansão. Um exame de tempos e dias passados com um enfoque no círculo interno kachruviano pode apresentar um espelho para examinar; (i) preconceito contra bilinguismo e multilinguismo, (ii) migração de seres humanos e o tratamento de imigrantes, (iii) respeito (ou falta de) dos direitos linguísticos e culturais de minorias e (v) a hegemonia do Inglês com relação a outras línguas- temas que nos preocupam hoje e também nos anos vindouros.

PALAVRAS-CHAVE: modelo de três círculos, imigração, multiculturalismo, diversidade étnica, preconceito, monolinguismo. 
... most of the European countries today are not pure countries made up entirely of white people. There's a very large Indian community in England, there's a very large

Muslim and North African community in France, in Germany, Sweden, and in Italy. The world is a mixed world.

(Edward Said, 2001, p. 245)

\section{Using circles to map the world (only English)}

Braj Kachru’s pioneering model (1982, 1985, 1986, 1990, 1996, 2003), representing the growth and spread of English in the world, has been invaluable for researchers in the field of Applied Linguistics to come to grips with the implications of the pervasive, highly complex and frightening presence of the language in this second decade of the twenty-first century. Kachru (2003) views the world as being divided into different circles: the inner circle, in his words, “... refers to the traditional bases of English", that is, in countries where English is the native language or L1 (United Kingdom, USA, Canada, New Zealand, Australia); for the author, the outer circle consists of "... a large speech community with great diversity and distinct characteristics" (Singapore, Philippines), while in the expanding circle, "English is an international language" and characterized by "performance (or EFL) varieties." (Chile, Holland) (p. 9). ${ }^{2}$ No doubt speakers from all the three circles "perform" in English in different ways according to the contexts in which English is employed.

\section{The agony: "Torn between the norms" Bamgbose; the ecstasy: English is everywhere, but not available for all people}

Kachru (1996) problematizes, on one hand, the role of English for its "ecstasy" and, on the other, for its "agony". The former refers to the fact that English is everywhere and bestows privileges on those who acquired the language at an early age or have learned it formally in schools, while the latter notion refers to the plight of those who have not had the opportunity to learn it (and may not be in a state of ecstasy!). No doubt the agony refers to the struggle about whose norm (British, General American, or Indian English?) should be legitimatized in the face of a checkerboard of different varieties of

\footnotetext{
${ }^{2}$ The notion "performance varieties" is problematic for we all "perform" with language no matter what variety we speak.
} 
English in use in the world today. Kachru has to be given credit for his defense of Indian English and Nigerian English as institutionalized varieties of English in the light of Quirk's (2003, p.9) insistence that that British English or General American be held as the yardstick of "Standard English". D'Souza (1997, p. 93) points out that English has been present in India since the mid1700 's and has become the language of government, the press, and the elite. English-medium universities were established in the middle of the nineteenth century in Calcutta, Madras, and Bombay (now Mumbai). He concludes that it is a myth to view Indian English as being both "new" and "non-native".

Kachru (1986) points also to the alchemy of English for the tongue has taken on different uses in the world and those who speak (and write it) appropriate the language to perform varied roles in the large number of communities of practice where English is employed at different levels be they international, intra-national, on one hand, or at the national, regional, local or "grassroots" levels, on the other.

\section{The explanatory power of models}

While the Kachruvian model has served as an important heuristic for understanding the pluricentricity of English as a global language, it has been criticized by a number of scholars: Jenkins (2003), Bruthiaux (2003), Park and Lee(2009), and Pung (2009). This state of affairs exists, no doubt, because models, being artificial constructs, fail to reveal the myriad scenarios in the 196 or 200 countries $^{3}$ in the world where English may be used as an L1 (native language), as an L2 (Second Language), or an FL (foreign language). It would appear, however, that researchers tend to expect far too much from models. Saussure, quite some time ago, claimed that "all grammars leak", and one might add that models themselves leak, that is, they fail to tell us all we would like to know about the status and role of English in the world. Bruthiaux (2003, p. 172) sums up nicely the problems with models: "[T]o be sure, no model of a complex phenomenon such as language variation can hope to account for every local twist in the sociolinguistic plot."

\footnotetext{
${ }^{3}$ Rosenberg (2003) states there are at the present time 196 countries, while Tucker (1997, p.3) says that there are "approximately 200 countries in the world. It all depends on what counts as a country or nation for some are not recognized by all. For example, China does not recognize Taiwan as a sovereign country.
} 


\section{Using words to cut up the world}

The problem with models and the drawing up of circles means that we are dividing up the world with the use of metaphors. We can point to "blocs" of countries, the "north-south divide", "East and West dichotomy", the "francophone world" or the "Arabic-speaking world", the "First World" vs. the Third, the developed world vs. the semi-developed world, as well as an underdeveloped one, and the "free" one and the supposedly not so free. We all remember the image of the "Iron curtain" countries. Eckl and Weber (2007, p. 17) contend that notions like "North-South divide" suggest an "oversimplification" suggesting a "clear-cut divide" between what lies to the north or to the south. In the authors" words: "[L]anguage matters: words create and shape our understanding of the world, and we base our judgments and decisions on them" (p. 18).

It is common knowledge that Australian and New Zealand have received waves upon waves of immigration from Britain and other countries over the years, and the two nations have a high standard of living, are modern (or post-modern), part of "Western Civilization", but both countries are located in the East and to the South.

With regard to the East/West dichotomy, Kobayashi (2011) points to the danger of essentializing Chineseness or Japaneseness by people in the West; in passing Kobayashi cites Kumaravadivelu $(2003)^{4}$ who contends that the stereotyping of Asian students unfortunately "...helps to reduce and unmanageable reality to a manageable label” (p. 567).

\section{The native speaker mystique}

The contribution of Kachru's three circles construct of English is that it brings to center stage that the world is multilingual, multilingualism is the rule, and monolingualism is the exception.

Giving the "inner" circle pride of place stresses the position of the "native speaker" and the mystique that surrounds the native as being an authority on her language speaking a supposedly "pure" form linked with genes or blood and place of birth. They are almost god-like creatures for some individuals who view "native speakers" with reverence. Bonfiglio (2010) questions the term (due to

${ }^{4}$ Cf. B. Kumaravadivelu. Problematizing cultural stereotypes in TESOL. TESOL Quarterly, v. 37, n. 4, p. 709-719. 
its racial overtones) and prefers instead to refer to those users as L1 speakers of English. Schmitz (2009, p. 343-346) presents a typology5 of the term "native speaker" and classifies him or her as "age of acquisition learners" (p. 7). In addition, those native speakers or, better still, L1s in Sydney, Seattle, or Salisbury are a varied group, all with different varieties and different levels of formal education. Some of those speakers go about their daily lives not at all concerned about obeying the rules of the prestige varieties in those places.

\section{Models and their limitations}

Jenkins (cited in Pung, 2009, p. 15) makes a number of salient points in her criticism of Kachru's model. ${ }^{6}$ In Jenkin's view, to consider that the construct can actually be used to determine the proficiency of speakers in English or to explain that the role of English for Special Purposes may demand a great deal of information from a model in the form of only a visual representation. Pung (2009) also refers to Bruthiaux's (2003) criticism that the model, on one hand, fails to explain variation in the different dialects of English, (indeed a very demanding task!) and, on the other, that the Kachruvian construct is unable to function as a guide for other world languages as French or Spanish, also a complex undertaking. Pung (2009, p. 4), however, in comparison with the large number of models proposed by other scholars for World Englishes, is the only researcher who attempts to propose a model useful for the analysis of other languages. His proposal for a Conical Model of English (CME) is indeed interesting for his idea originates from another conical model of English proposed by the distinguished phonetician Daniel Jones (modified by Ward (1956). Jones' model, according to Pung (p. 58), “... while targeted at capturing and describing the phonetic landscape of English, provides an interesting basis that can be extended to represent English as it exists in the world." (My emphasis). This author contends that his conical representation can be used to describe Languages of Wider Communication (LWCs), in particular the "global French language speech community", and

\footnotetext{
${ }^{5}$ In addition to "age of acquisition-natives", Schmitz includes in the typology the following: "the loyalty native", "objective proficiency native", "the Chomskyan ideal native speaker", "blood native", and the "historical-antecedence-native" (SCHMITZ, 2009, p. 344-346).

${ }^{6}$ Pung (2009, p. 15) summarizes Jenkins's (2003, p. 14-21) critique of the three circles model.
} 
serve as a Conical Model of Language (CML) that is used for all languages and their respective communities (Figure 1 below).

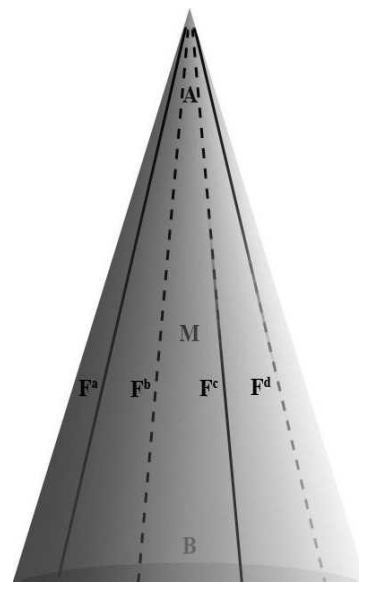

FIGURE 1 - Conical Model of English, Pung, (2009, p. 67). $\mathrm{A}=$ acrolect, $\mathrm{M}=$ mesolect, $\mathrm{B}=$ basolect, F 1, F $2=$ linguistic Fellowships]

According to Pung, at the apex the letter A stands for the acrolect or formal (standard variety of French); letter $M$ would refer to an intermediate variety and the basilect would be that variety distant from the acrolect or standard form. Pung's study of the three-circles model and the criticisms leveled at it are indeed useful for students of World Englishes, but models do not tell us very much about the underlying tensions and biases with regard to the use of language(s) in societies or fellowships as Pung would have it. In the case of Singapore, the model fails to point out whether or not all speakers speak standard Singapore English all the time (my emphasis), or switch to Singlish, employing it always, while never using the Standard English (British or General American). Looking at the model, we do not know how many Singaporeans adhere to the "Speak Good English" campaign to encourage linguistic homogeneity. Tan $(2005$, p. 171) is intent on teaching standard (inner circle varieties, either British or American) English in language institutes where, for her, "interference" from Chinese or Malay would be discouraged. The research by Bao (2003, p.40) points to social stigma and diglossia with regard to Singapore English in contrast to "exonormative native English", and this creates a serious sociolinguistic problem for that country. It is doubtful that Singlish will disappear either on its own or by government decree. 
Standard language ideology is a problem for expanding circles nations, as is the case in inner circle countries, as we will observe (in sections 4.1-4.4).

\section{Looking beneath the surface}

Pung (2009) proposes to "go beyond" the three circle model with his consideration of a Conical Model of English (CME), while Park and Wee (2009, p. 402) state that models have no "magical efficacy in challenging dominant ideologies of English" and that change in the world is not brought about by models but by people. Based on Park and Lee's caution with regard to language models and in the light of Pung's choice of the preposition beyond in his words "going beyond" the well-known model, the thrust of this paper is to change the preposition and look under the Kachruvian proposal that functions as a palimpsest erasing and ignoring what happened in the past linguistically, historically, and culturally. This looking "below" or "under" brings to mind Joshua Fishman's piercing remark about the apparently hidden linguistic reality in the USA. In his words, " $\ldots$ the English language in the United States, is like the Mississippi River, a mile wide but frequently only an inch deep- with other, perhaps deeper rivers flowing below it" (quoted in TRIMBUR, 2008, p. 142).

It is to be expected that the various practitioners in the burgeoning field of World Englishes focus on the English language and its spread in the world. All these studies are linked, even if they are located in different university departments, to English or English studies and adhere to the discipline as a locus of enunciation for survival in academia, no matter what ideological position they follow. English is indeed part of their livelihood and their career; some may view it as not being "natural, neutral and beneficial" (PENNYCOOK, 1994, p. 7), while others contend that the language "is displacing and replacing local languages rather than functioning as an 'auxiliary' or 'additional' language (PHILLIPSON, 1992, p. 282) or a "linguistic cuckoo" (PHILLIPSON, 2006). Others may consciously (or unconsciously) hold a celebratory or triumphant view with regard to the presence of English in the world. A possible example of this stance is the belief that knowing English functions

\footnotetext{
7 The cuckoo lays its eggs in other birds' nests. For the author, English is like a cuckoo for it is everywhere and appears bottom-up via popular culture and topdown owing to its use by universities, publishing houses, the media, and by governments in countries where it is official.
} 
as a "passport" to being a world citizen. People have the right to learn languages of their choice.

Foucault (1979, p. 218) views the existence of disciplines as "a technique for the ordering of human affairs". TRIMBUR (2008, p. 166) maintains that allegiance to a discipline functions "as a kind of loyalty oath"; for Fishman (cited in Marckwardt (1968, p. 50-51), there has existed, since the days of founding of the United States, an "... ambivalence toward English that has characterized the unsettled linguistic history of the United States". For some (but not for all!), the "love of English" is often dangerously equated with love of the nation, with its dissemination by native speakers and the maintenance of a standard (=native form). Trimbur (2008, p. 166) argues for an examination of the "ambivalence" with regard to the language that "... has characterized the unsettled linguistic history of the United States." In this regard, Pennycook (1994, p, 141) censures both linguistics and applied linguistics for "... spreading the word and the disciplining of the language".

The Kachruvian three-circle model appeared in the mid-1980s. However, the cornerstone for the diffusion of English in the world was put in place in 1966 long before the birth of the three circles owing to the organization of "The Anglo-American Seminar on the Teaching of English" or the Dartmouth Conference. The conference functioned as an AngloAmerican alliance to spread English throughout the world. The main promoter of the conference was the linguist Albert H. Markwardt who organized the text Language and Language Learning (1967) published by the National Council of Teachers of English. Markwardt was one of the catalysts, on one hand, for the USA-United Kingdom "exportation" of English to all nations as a commodity and, on the other, for bringing English home as a mother tongue and as a mark of " national unity" (TRIMBUR, 2008, p. 152). It is worth noting that the other inner circle countries (Canada, Australia and New Zealand) were not consulted. Trimbur (2009, p. 143-144) sums up the political and economic strategies underlying the meeting (and the many other meetings held in the 50s). Here are his remarks:

Seemingly far removed from the neocolonial Cold War policies of an emergent ELT industry, those gathered at Dartmouth nonetheless participated in the establishment of a virtual gold-standard of English as an export commodity by identifying English with the figure of the native speaker at home in the metropolis. 
The underlying motivation for the concern with English in both Britain and the USA was due to falling standards in schools and college at that time in the area of writing the respective standard varieties of English. Those involved in the teaching of composition examined the notion "native speaker" and particularly young native speakers (my emphasis) whose writing showed "interference" from informal spoken English, regional variation, and, in some cases, other languages spoken at home as well as, for some students, impatience with the task of writing.

\section{Ignoring the past}

Those who deal academically with English and globalization have tended to erase history. In the literature on the presence of English, there is very little written about what the inner circle spaces (Australia, Canada, etc.) were like, before (my emphasis) they were conceived as "circles" and English was inserted in those localities by (i) emigration from Europe and Africa, either voluntary (early settler- pioneers) or obligatory (indentured servants and slaves); (ii) mass migration or diasporas of people who fled oppression in their countries of origin); and (iii) in recent times, asylum seekers.

\section{The Inner Circle or the so-called "native speakers" club}

\subsection{The birth of English}

The British Isles that include England, Wales, Scotland, and Ireland were multilingual. In addition to Anglo-Saxon, and later on English, a number of Celtic languages, namely Breton, Cornish, Welsh, Scots Gaelic, and Irish Gaelic flourished at different periods of history, but those languages were often repressed. One such case is the fate of Irish Gaelic. Ó Cathail (2007, p. 114) writes the following: "By and large, from 1366 through the nineteenth century, British colonial rulers argued precisely for the extermination of the Irish language as a larger political project".

This quote concerning Britain's first colony is telling for it points to what nation-states have done with languages and to the different peoples who wish to maintain them. The use of the label "The British Isles" was not wellreceived by the Irish and no doubt for some Welsh who declare that they are not "British". The notion of one country and one language, with the construction of a sole identity, setting the stage for scenarios of monolingualism, 
nationalism, and racism, has not disappeared. Britain is far from being an exception. With regard to Britain's neighbor across the channel, Jeanjean (2006, p. 93) states, quite despondently, that “...there is little hope of ever seeing a government willingly redress the blatant inequities of the centuriesold French linguicide ${ }^{8}$ policies" that attempt to suppress regional languages in the country: Occitan, Alsatian, Breton, Corsican, Catalan, and Basque (p. 93, n. 1).

Innes (1993) laments the demise of Gaelic in Scotland from the tenth to the twentieth centuries and recognizes that it is difficult "... to find a role in Scottish life and affairs" for the language. He states that the language "cannot be restored to its former position in Scotland because of the history of persecution it has suffered." Scotland will go to the polls in September 2014 and voters will be asked to answer the question "Should Scotland be an independent country?” Whether independent or semi-autonomous, it would take some doing to revive Scots Gaelic.

In the late nineteenth century and early years of the twentieth, according to WALES HISTORY BBC CYMRU/WALES, Welsh children had to wear around their necks the - "Welsh Not" - a block of wood to punish them for speaking Welsh.

Physical punishment for speaking a specific language has ceased and nowadays there are movements to encourage the study and use of Irish Gaelic, Scotish Gaelic, and Welsh in the United Kingdom. According to the BBC News, there are approximately a half a million people who speak Welsh (no doubt mostly in Wales).

\section{Transformation: from a strongly monolingual society to a multilingual one.}

The United Kingdom is indeed nowadays a multilingual society with different individuals who speak various Indic languages as well as Polish, Arabic, French, Chinese, Portuguese, and Spanish, as Table 1 indicates:

\footnotetext{
${ }^{8}$ Phillipson (1988, p. 339) uses the term linguicism “... the ideologies and structures which are used to legitimate, effectuate and reproduce an unequal division of power and resources.... between groups based on language."
} 


\section{TABLE 1}

Ranking of the ten most used ethnic languages in the United Kingdom, excluding English and regional languages

\begin{tabular}{lr}
\hline Language & Number of Speakers \\
\hline Polish & 546,000 \\
Punjabi & 273,000 \\
Urdu & 269,000 \\
Bengali & 221,000 \\
Gujerati & 213,000 \\
Arabic & 159,000 \\
French & 147,000 \\
Chinese & 141,000 \\
Portuguese & 133,000 \\
Spanish & 120,000 \\
\hline
\end{tabular}

Source: The Independent, May 22, 2013. Available at <www.independent.co.uk>. Accessed May 12, 2013.

The number of speakers does not come close to the massive number of speakers of Spanish $(34,183,747)$ or Chinese $(2,455,283)$ in the former "British America", the USA (see Table 2). The number of speakers is lower than in the USA, and only Polish has enough speakers to figure as $1 \%$ of $49,808,000$ speakers of English in the UK. Before examining the USA and its tense situation due to the supposed or imagined "threat" of Spanish and Chinese, Harris, Leung, and Rampton (2001) [henceforth: HLR] have a lot to say about the present-day situation as regards immigration, bilingual education, and English-language teaching in the UK. It is curious that, in many, many instances in their text, the authors refer to England and to a lesser extent to Britain and only once to the UK. This might mean that the speakers of languages other than English are located more in England than in Wales or Scotland. The authors do not mix words stating that the English Education Policy has “ ... failed to engage adequately with multilingualism in a globalized world” (p. 1). This is a very serious admission.

\section{Globalization}

HLR tell us that globalization and diaspora "have changed the way we conceptualize language, ethnicity and the nation-state" (p. 1). Nation-states were historically constructed to forge people into the same mold, as Bell (2001, p. 216) nicely puts it: “. .. reshaping human society into some sort of ideally harmonious order was seen as the central task for human beings to accomplish". 
The three authors follow the work of Cameron McCarthy (2005) who argues that the existence of hybridity in the world today has pointed implications for teaching English and other subjects in inner circle schools; those concerned with what HLR (2001) conceive as "multilingual education" need to look at "the contemporary reality of students' (p. 1) lives in a postcolonial, globalized, market-driven world in which schooling is only one of numerous stances available for the negotiation of both identity and culture" (p. 8). The notion of globalization is singled out by the authors for, in their view, the very relationship between nation-states, ethnic diversity and "language education" has been challenged by the phenomena of globalization in the course of the last fifteen years.

One problem in this regard is that the term "globalization" can easily become a buzz word for it is really a lot older than fifteen years. The United Kingdom is indeed an example of globalization for the nation created a global empire where "the sun never sets". Even in this so-called post-colonial period, the mark of former British imperial power can still be observed throughout the world.

For Guillén (2001, p. 235), "[G]lobalization is one of the most contested topics in the social sciences". This author has some interesting things to say about the notion: he comments that it [globalization] "began with the dawn of history" (p. 237); he refers to the years 1519-1521 when the Earth was first circumnavigated; he also points to a myriad of events as the "timezoning of the world", "the near global adoption of the Gregorian calendar" and the "establishment of international telegraphic and signaling codes" (pages) at the present time almost forgotten with the advent of the Internet. In Guillén's words:

... there is no agreement as to whether it was Magellan and Mercator, James Watt and Captain Cook, Nixon and Kissinger, or Thatchter and Reagan that globalization started, or to be more precise, that the narrative of globalization ought to begin. (p. 238).

Returning to HLR, their article contributes to a new understanding of immigration and the plight of immigrants to Britain; they present a critical analysis of the Swann Report ${ }^{9}$ that failed to deal with the linguistic minorities

${ }^{9}$ HLR present a critical analysis of a British government document called the Swann Report (1985) "Education for all". The problem was that the Report insisted on learning good English and rejected bilingual education with the teaching of English and a minority language. (Available at <www.sociology.uk.net/page/65>. Accessed June 20, 2013). 
in the United Kingdom for it considered them to be all "settled, stable and well-defined" ( p. 2); it tended to treat all immigrants alike with no distinction made between old-time minorities and new arrivals. The report ignored the fact that the different bilingual or multilingual groups had and still have connections with their respective homelands; they are in fact "transnationals" who move to and fro between inner circle Britain to the Caribbean, to South East Asia, and to the European Continent. Many enjoy the opportunity of having a foot in the "center" with its high standard of living and many social benefits, as well as having another foot in the so-called "periphery". HLR put their finger on the major tension underlying many programs organized by nation-states that attempt to assimilate ethnic minorities, trying to make them British, American, or Canadian. Nationality cannot be thrust on people. First of all, courses in English as a second language are of little interest for the transnationals who are at ease with their bilingual (or multilingual) status and, according to the authors, are able to "manage their own diasporic identities while resisting full assimilation to the new nation." (p. 4). Not all want to speak Standard British English for they are content with their own variety of English.

No mention is made in the paper about the different ethnic groups. Speakers of Indian languages and those from Jamaica have had a different relationship with English, one might imagine, than those who speak Chinese or Polish. We are dealing with people, quite interestingly, who have, in HLR's (2001) view, "transnational and subnational identities". This situation is a challenge indeed to the nation-state as it stands today with its one people/one language/one nation ideology. HLR, it would appear, are suggesting that a multilingual bias is present in the country that is intent on nationalizing the different ethnic minorities who reside in metropolitan cities in Britain while those same minorities prefer to maintain cultural differences. HLR (2001, p.6). present a true picture of what is happening in all of the inner circle countries today:

Ethnic and cultural difference are highly salient, and subculturally specific resources- food, dress, music, speech - can be aestheticized and/or commodified, used in artistic production or sold commercially to a wide range of different consumers and not just to tourists and the transnational elite.

HLRs' (2001) article points to the necessity of reconsidering what it means to be British. If it means speaking Received Pronunciation (RP) or what 
the authors consider "a posh variety" of the language, many of the ethnic minorities are in fact located indeed in another world:

... where creoles, patois and Black English decenter, destabilize and carnivalize the linguistic domination of "English"-the nation-language of mater-discourse-through strategic inflections, reaccentuations and other performative moves in semantic, syntactic and lexical codes (p. 6).

In more recent studies in the research on (English) language education, Jenkins (2007), Seidlhofer (2011) examine a new paradigm in teaching English, that is, English as a Lingua Franca (ELF) that has a growing number of speakers in the world, particularly in Europe and other expanding circle nations. With the movement of peoples throughout the world, one might conjecture that there are speakers of ELF in inner circle countries as well. Official testing programs based on L1 standard language norms often rate immigrants as being deficient linguistically with "unintelligible" accents.

Based on HLR's study of ethnic minorities in Britain, it would seem to be a wise policy to start from a bottom-up strategy rather than a top-down one. The nation-state must change its stance and listen to the different groups, respecting the crossing of linguistic and ethnic borders that are part and parcel of "glocalization" ${ }^{10}$ in major UK cities at the present time.

In section (4.2), we turn to a nation that broke away from the "mother country" via two bitter wars, the American Revolution and the War of 1812. It is no surprise to many of us that those colonists, who fought for their rights as Englishman and severed their connection with their homeland, slowly but surely embraced English, baptized it as "American English", cherished it, and, in many instances, thrust it over the human rights of "others".

\subsection{An "English" colony that goes its own way: the United States}

The colonists in the thirteen colonies who severed ties with the British Crown and with their "British brethren" (as stated in the Declaration of Independence) from the early years of independence rejected languages other than English. It is telling that two "Founding Fathers" of the USA, Benjamin

\footnotetext{
${ }^{10}$ The term glocalization was first coined by the sociologist Roland Robertson to refer to adjusting fast food to local markets, preferences and customs. For example, in India, the McDonalds enterprise serve vegetable hamburgers ("McVeggies") for cows are sacred and meat is not eaten in many parts of the country.
} 
Franklin and Thomas Jefferson, according to Hendrickson (1986, p. viii), harbored monolingual sentiments in favor of only English. And much later on, President Teddy Roosevelt, stated categorically that the USA has "... room for but one language here" and went on to declare that Americans should not be "... dwellers in a polyglot boarding house" (p. viii). It is no surprise, therefore, that the formation of a monolingual mindset began very early in the USA and prepared the ground for English-only issues that appeared in the 1980s. Schmitz (1993, p. 236) has this say about a book published at the height of that (and still to this date) very emotional issue:

... the movement in favor of the exclusive use of English and the official recognition of the language is due, on their part, to the fear that certain monolingual citizens feel threatened by the use of a language that they do not understand. Some of these monolingual speakers cast doubt on the loyalty of people who speak and use other tongues as if knowing another language makes them less American (my translation).

In a review of Bonfiglio's (2002) Race and the Rise of Standard American, Walicek (2002) informs his readers that the author contends that the process of the standardization of English in the United States was "quite distinct from that of other countries" (p. 1). Walicek considers the contribution of the book to be in the author's uncovering of the fact that standard American was based on mid-western English "... shaped on a paranoid reaction to eastern immigration and a celebration of the American frontier that in terms of linguistic capital ultimately devalued the local varieties spoken in New York and Boston" (p. 4). This xenophobic stance motivated the appointment of a faculty committee at Harvard University in 1922 to examine the increase in the enrollment of Jewish students; the committee "constructed" as their model "the Nordic Christian (mid)western country boy". Indeed a look into history can shed light on where we stand today; the circles, for the most part, are not at all helpful when one delves into the past. Immigrants with languages other than English were early on viewed as a problem. A monolingual mindset had an early birth in the country as well as in other inner circle countries, as we will observe.

Viewing the United States as an inner circle nation, replete with solely "native speakers" of English, is misleading. Gonzalez (2001, p. 207) presents a different picture. In his words: 
In fact, $w e^{11}$ are in the unique position of being not only the largest English-speaking country in the world, but also the fifth largest Spanish-speaking one, surpassed only by Mexico, Spain, Argentina and Colombia.

Table 2 Shows the ten most spoken languages in the United States.

TABLE 2

Ranking of the ten most used ethnic languages in the United States excluding English and Native American Languages

\begin{tabular}{lc}
\hline Language & Number of Speakers \\
\hline Spanish & $34,183,747$ \\
Chinese & $2,455,583$ \\
Tagalog & $1,444,324$ \\
French & $1,358,816$ \\
German & $1,120,670$ \\
Vietnamese & $1,204,454$ \\
Korean & $1,048,173$ \\
Russian & 846,233 \\
Italian & 807,010 \\
Portuguese & 678,334 \\
\hline
\end{tabular}

Source: American Community Service on language data, United States Census Bureau. Available at <www.census.give/acs/www> . Accessed May 30, 2013.

In his lucid book, Gonzalez (p. 208) traces the history of the waves of immigrants who are part of the history of the country. The first group includes those who came to the USA from Europe and Asia who severed their ties with their respective countries of origin and adopted "... the language of the new country" and accepted "... a subsidiary status, if any, for their native languages." The second group consists of the African slaves from different regions of the African continent who arrived "... in chains, forced from the start to give up their various mother tongues, and not permitted even to acquire a reading or writing knowledge of English so that the slaveholders could more easily

\footnotetext{
${ }^{11}$ Note that the pronoun we has been italicized to make it clear that Gonzalez is speaking as a citizenof the USA. He was born in Puerto Rico and grew up in New York City. Gonzalez is a columnist with the New York Daily News and was awarded the George Polk journalism award in 1998.
} 
control and dominate them." Gonzalez's third grouping includes "... those people who were already living (my emphasis) in the New World when their lands were either conquered or acquired by the United States." For the author, "the conquered nationalities" (or "annexed" Americans) include Native Americans, French Creoles from Louisiana, Mexicans, and Puerto Ricans who were declared citizens "without any vote or petition of their part" (p. 208). They were all far from having the status of foreigners. Spanish, Cajun, and the Native American languages are "...tongues of long-settled linguistic minorities who were absorbed by a multinational state" (p. 212).

American historians, or to be precise, Anglo historians, in their zeal to construct a sole identity for the nation, ignored the presence of the others in the United States, and Gonzalez's book is indeed a rewriting of history.

Compared with the other inner circle or "native speaker" nations (see 4.3 and 4.4 below), the United States, throughout its history, has suffered a number of "battles over language", earlier on with the presence of German immigrants in the USA whose right to use their heritage language was repressed in the late $19^{\text {th }}$ century at both the state and federal levels. Moreover, the two wars with Germany in the $20^{\text {th }}$ century discouraged the use of German; other such battles can be seen in the struggle of the Native Americans for preservation of their languages and cultures, as well as the Mexican populace, who had lived in the country long before the Declaration of Independence of the United States in 1776, but who were deprived of their lands, as was also the case of the indigenous population. In the case of Puerto Rico, the country was declared bilingual "even though its population had spoken Spanish for four hundred years and almost no one spoke English" (GONZALEZ, p. 210). It was President Franklin D. Roosevelt who insisted on an "English only policy" for Puerto Rico. Spanish is still the language of the island.

The issue of language in the United States is indeed an emotional one and, in comparison with the other inner circle countries, has resulted in legal measures to make English the official language of the country in the wellknown "English-only movement". Worse still, the heated debate with regard to English and the presence of different languages with differing customs and cultures has prepared the terrain for men like Arthur Schlesinger (1917- 2007) and Samuel Huntington (1927-2008). Based on the often tense situation peculiar to the USA, it is difficult to imagine a movement to legislate Englishonly in Britain thanks to the presence of Welsh, Irish, and the plebiscite in 2014 for the independence (or not) of Scotland. 


\section{A xenophobic historian?}

First, a word about Arthur Schlesinger, a celebrated American historian who has to his credit a vast number of books and scholarly papers dealing with varied aspects of US society. Schlesinger spares no words about the transgressions of white European settlers who "... overran and massacred" the indigenous peoples, "or hauled in against their will from Africa and Asia", thousands upon thousands of people placing them all "beyond the pale". The historian points to a sad record with the following words: "We white Americans have been racist in our laws, in our institutions, in our customs, in our conditioned reflexes, in our souls" (p. 18-19). These remarks are surprisingly absent from elementary, high school, and college history books used in the USA.

His "confession" with regard to a racist history is abruptly spoiled by a series of contradictory statements that lead one to doubt his sincerity. Here are a few of them:

“... new laws eased immigration from South America, Asia and Africa and altered the composition of the American people" (p. 19).

"The ethnic interpretation, moreover, reverses the historic theory of America as one people -the theory that has thus far managed to keep American society whole." (p. 20).

"The historic idea of a unifying American identity is now in peril- in many areas, in our politics, in our churches, in our language" (p. 21).

His remarks do not auger well for multiculturalism and multilingualism and ethnic diversity in the USA. As a distinguished historian, Schlesinger is viewed by the general public and by some intellectuals as an "authority" and no doubt many people with racist views and intolerance of the "other" will subscribe to his way of thinking.

\section{Multilingual bias?}

Let us now turn to Samuel Huntington, another distinguished scholar, who also presents polemical remarks with regard to immigration of different peoples to the USA, specifically Latin Americans, a scenario that points to a fear of multilingualism and multiculturalism. According to Huntington, immigration is destroying the "original" identity of the USA. 
In a review of Lacoste and Rajagopalan (2005), Schmitz (2010) refers to one of the articles in the volume, "The Hispanic nightmare of Samuel Huntington" [(O pesadelo hispânico de Samuel Huntington $]$ signed by the Frédérick Douzet, a noted French political scientist. Here are the reviewer's thoughts:

The very fact that Douzet is a citizen of France, a bilingual European with substantial residence time in the USA as a researcher in geopolitics permits her to examine Huntington's remarks academically. Nobody is neutral, to be sure, but as an "outsider", Dauzet is not emotionally involved in the sensitive issue of immigration or whether or not the Hispanic presence is a threat to English and the "American way of life" (whatever that may mean) (p. 507).

At the very top of Huntington's article "The Hispanic Challenge" published in Foreign Policy (July 10, 2010), there are some frightening words which reek of intolerance, a closed mind, and a reverence for the past. The author declares:

The persistent inflow of Hispanic immigrants threatens to divide the United States into two peoples, two cultures, and two languages. Unlike past immigrant groups, Mexicans and other Latinos have not assimilated into mainstream U.S. culture, forming instead their own political and linguistic enclaves-from Los Angeles to Miami-and rejecting the AngloProtestant values that built the American dream. The United States ignores this challenge at its peril (HUNTINGTON, 2004, p.1).

\section{A challenge to xenophobia and to the monolingual mindset}

The authors' remarks may not auger well for future years. To be sure, Huntington and Schlesinger have the right to think and write what they want. Freedom of speech is indeed the golden rule. Fortunately however, Huntington's and Schlesinger's ideas have been seriously questioned by the work of James Crawford who has published widely in an attempt to expose the anti-immigrant and racial stance on the part of Americans who would curtail immigration and force a monolingual English-language policy on all who live in the USA. This is what Crawford has to say in his Hold Your Tongue (1992): 
....it is the consensus among Latino leaders, from rightist Cubans to liberal Chicanos to radical Puerto Ricans that English Only has united them like nothing else in recent memory. They perceive it to be a campaign of intolerance, aimed in particular at Spanish and its speakers. To their ears "the legal protection of English" sounds a lot like "equal rights for whites": a demand inspired by the paranoia of the dominant group, a backlash against Hispanic advances in civil rights, education, and political empowerment. In a word, racism.

Crawford's argumentation is crystalline. He observes that it is ironic that while English spreads throughout the word like wildfire, people in the USA are insecure about the presence of large numbers of Latinos in the country and feel uncomfortable with new immigrant communities in their midst, as the Vietnamese "enclaves" in small towns in Arkansas and Kansas. People who have visited Miami, Florida, or Monterey Park, California will not fail to note the presence of Hispanics and Chinese, respectively, in those two cities. The fear of many monolingual Americans is that the immigrant groups will continue to speak their languages and will not learn English. What is reassuring for those concerned monolinguals is the fact that "...today's immigrants are learning English faster (Crawford's emphasis) than ever before." This is the real contribution of the book and a counter-argument to Schlesinger/Huntington who contend that Hispanics and Chinese are becoming "nations" in a nation. Crawford's questioning of the English-only policy and his deconstruction of chauvinism are essential for unemotional, respectful, and open-minded debate about immigration, linguistic diversity, and the view of multilingualism as a national resource, and not as an indicator of disunion, are indeed in order.

Referring back to Britain for a bit of comparison with the USA, it is interesting to observe that the UK has not produced individuals like Arthur Schlesinger or Samuel Huntington who fear that the United States will be torn apart by its ethnic diversity, particularly by the presence of Latinos. Britain, however, has produced a John Honey (1997) who cherishes Standard English and looks askance at those who do not speak the standard. Such a position may be dangerous for it tramples on the right of those who, for their own reasons, do not wish to speak the prestige variety and indeed live happily with "I ain't going nowhere today", "See them books on the table over there", "She don't want to go (wanna go)". Intolerance with respect to linguistic variation in the mother tongue facilitates a move in the direction of discrimination toward ethnic minorities who are accused of not speaking (or not willing to speak) "proper English". Lippi-Green (1994) refers, in this 
regard, to linguistic minorities who speak with an accent (who doesn't have an accent?) and are discriminated against at the workplace even when their pronunciation and intelligibility in no way interfere with their on-the-job performance. The author calls it Linguistic Trait Discrimination or LTD.

In the next section (4.3), we move to the north of the United States to examine the role that language plays in Canada, a nation- state that has two official languages, English and French, in addition to ethnic languages and "first nation" languages spoken by the indigenous peoples.

\subsection{The neighbor to the North: Canada}

Both Canada and its "Southern" neighbor have incorporated as citizens indigenous groups (respectively, Native Canadians or Native Americans) who never, in most cases, requested citizenship in the respective countries where they reside. The crossing of the oceans of the world by Europeans (an example of globalization!) to populate and plunder the New World led to the massacre and eventual subjugation of the Indians in North America (and of the Aborigines in Australia and New Zealand).

Few people are concerned with the injustices perpetrated on the indigenous populations in the Americas, both in the North and in the South. Their condition is rarely linked to the difficulties that ethnic minorities have faced in the past and are facing at the present time. The story of the Native Americans or First Nations serves as mirror that must be considered in dealing with the treatment of ethnic minorities today in inner circle countries. To get a true picture of what happened in the past, one needs to look to another area of knowledge and not exclusively to sources in the area of language and linguistics. The field of Law and legal scholarship shed far more light on the fate of those who were present before the European exodus to the Americas. For example, legal scholar Ralph W. Johnson (1991, p. 712) argues that, in the case of Canada and the USA: "[N] either country deserves accolades for dealing fairly with the aboriginal tribes within their borders." The behavior of fathers, grandfathers, great grandfathers (and so on) with respect to the original inhabitants is part of "forgetting". Johnson concludes "... the real policy of both governments was to move the aboriginals off the land and make it available for prospecting, logging, farming and settlement by non-Indians" (p. 713).

The lesson here is that an attitude of complacency or a view "that's the way things are" as well as a posture of silence about what went on before will not be of help in dealing with the language issues at the present time. 


\section{Canada: an experiment in official bilingualism}

In a seminal text by Meyerhoff (1994) published in the American International Law Review points to the Canada Act (or Constitution Act) of 1982 that permitted the nation to "control its constitutional destiny" (p. 913) for the first time in its history. The document provides the two official languages, French and English, "with the equality of status and equal rights as to the use of French and English throughout the federal government" (p. 916). The basic problem with respect to multilingualism (and multiculturalism) in the country, according to Meyherhoff, is that the constitutional provisions "recognize cultural, but not linguistic equality for ethnic minorities" (p. 918). The author points to a quandary for the country:

Canada is unlikely to relinquish its problematic model of language rights and multiculturalism. Linguistic dualism and a narrow definition of multiculturalism are rooted deeply in Canada's constitution-making. [...] To the extent that Canada remains wedded to the concept of linguistic dualism and advances a narrow definition of multiculturalism its stability will remain a source of concern (p. 1011).

An analysis of Table 3 below points to a problematic way of reporting Canada's linguistic minorities. Instead of specifying directly the number of people who speak Italian or Spanish, the speakers of those languages are placed in the Romance family while French (also a Romance language) is not, for it is viewed as an official language. Moreover, the notion Indio-Iranian family fails to tell us how many people speak, on one hand, Punjabi or Persian on the other, how many speak Hindi or Gujarati. Informing that almost 500,000 people speak a Semitic tongue does not clarify the number of speakers of Hebrew, Arabic, and Amharic that reside in Canada. We all know that English is a Germanic language, but it appears that it does not count as one owing to its official status. One gets the impression that the intent is to "hide" the numbers of ethnic minorities living in the country. 
TABLE 3

Ranking of the ten most spoken ethnic languages in Canada, excluding the indigenous and official languages (English and French)

\begin{tabular}{lc}
\hline Language & Number of Speakers \\
\hline Romance & $1.196,390$ \\
Indo-Iranian & $1.179,990$ \\
Chinese & $1.112,610$ \\
Slavic & 721,605 \\
Germanic & 611,165 \\
Semitic & 449,580 \\
Malayo- Polynesian & 443,750 \\
Dravidian & 175,280 \\
Austro-Asiatic & 174,450 \\
Greek & 117,890 \\
\hline
\end{tabular}

Source: Statistics Canada: "Table 1, Population of Immigrant Mother Tongue Families, Showing Main Languages Comprising Each Family, Canada, 2011”. Available at $<$ www.statcan.gc.ca/tables-tableau/sum-som/index. eng.htm or index.fra. htm>. Accessed: May 30, 2013.

While the country may not have a Schlesinger or a Huntington, it does have a site called "Forced Bilingualism in Canada" (www.forcedbilingualism incanada.com/Home_Page.php) that could produce similar problems leveled not only against French, but also against the ethnic and the First Nation languages. Of course dissent is a cherished right in a democracy and conflicting views need to be debated and negotiated peacefully. We all know the record of authoritarian governments, for example, of Spain during the years of Francisco Franco when Basque and Catalonian were prohibited and their speakers punished for speaking those languages.

In the following sub-section, we will look at the two inner circle nations in the Antipodes, firstly Australia and secondly, New Zealand.

\subsection{Down Under: Australia and New Zealand}

\subsubsection{Australia: an island, a continent, a nation, and a multilingual society}

For Bryson (2000), Australia is the sixth largest country in the world as well as the largest island. He writes: "It is the only island that is also a continent, and the only continent that is a also a country" (p. 19). Truly mind- 
boggling is the fact that the first Australians arrived there "... at least 45,000 years ago, but probably more than 60,000” (BRYSON, p. 241). But he asks his readers this:

When was the last time in any context concerning human dispersal and the rise of civilization that you saw even a passing mention of the role of the Aborigenes? They are the planet's invisible people (p. 247).

Pilger (1991, p. 15) refers to his country as a "secret country" based on the fact that Australian historians have ignored, until quite recently, the presence of aboriginal or indigenous peoples and have erased the story of cruelty on the part of the European settlers in the $19^{\text {th }}$ and $20^{\text {th }}$ centuries. The Australian political scientist Jasper Goss summarizes the tragic history of the first Australians with the words "the construction of Aboriginal absence" and the "naturalness of European ownership". That "naturalness" about the appropriation of the aboriginal lands in North America, Australia, and New Zealand on the part of European settlers and adventurers, as well the "naturalness" of the ideology of Manifest Destiny or "America for those of European ancestry" (GONZALEZ, 2000, p. 42) has been not been questioned in the new imagined communities. In Goss's words, "Australia became empty and ready for habitation, though if Aboriginal peoples are present they are equated with flora, fauna, and the landscape..." (p. 249).

\section{The "invisible" people become visible at long last}

There is a great amount of literature on the changing treatment of the indigenous Australians. They received the right to vote as late as 1967! And 1992 the High Court of Australia (Supreme Court) declared that the original British policy of declaring the land to be empty or uninhabited [terra nullius] and "free to be taken" by the European setters was judged to be null and void. One wonders how much land was returned or is being returned to the original owners. The critical reopening of history augers well for Australia and serves as an opportunity to redress injustices. A look at the past and the present-day changes in thinking present the nation with an opportunity to not commit the same injustices in the case of the newcomers to the country 


\section{Australia in the second decade of the $21^{\text {st }}$ Century: more and more multilingual and multicultural}

According to the document People of Australia: Statistics from the 2006 Census (Department of Immigration and Citizenship, Commonwealth of Australia, 2008) state that through migration Australia has become a culturally diverse country with peoples who come from more than 230 countries and speak more than 300 languages. Table 4 shows the ten most spoken languages in Australian homes.

\section{TABLE 4}

Ranking of the ten most spoken ethnic languages spoken in Australia, excluding English and indigenous languages

\begin{tabular}{lc}
\hline Language & Number of Speakers \\
\hline Italian & 316,893 \\
Greek & 252,228 \\
Cantonese & 244,548 \\
Arabic & 243,558 \\
Mandarin & 220,603 \\
Vietnamese & 194,855 \\
Spanish & 98,000 \\
German & 75,635 \\
Hindi & 70,008 \\
Macedonian & 67,832 \\
\hline
\end{tabular}

Source: Austalian Bureau of Statistics, 2006 Census. Available at <www.census.abs.gov.au/census/2006)>. Accessed May 15, 2013.

Clyne (2008, p. 1), speaking from the Australian context, considers linguistic diversity to be a blessing and considers it to be an "unrecognized recourses boom". He places the blame on the British navy and the waves of British immigrants for having "... introduced monolingualism as the norm to the Australian continent" (p. 1) even though many of immigrants were speakers of Welsh, Iris, or Scotish Gaelic. The author makes a good point when he reminds his readers that Australia was multilingual before (my emphasis) the arrival of English-speaking people and the subsequent eradication of things past. He reminds his readers of days-gone-by: "[W] hen the Warrunjeri people of the Kulin nation inhabited the land of which this university now stands (my emphasis), they were part of a multilingual continent in which most people needed several languages to communicate". 
He goes on to observe that while some of the European languages (German, Italian, and Greek) are no longer being spoken in Australian homes as frequently as they were in the past, there has been since the 1990s a marked increase in the country of speakers of Asian languages, particularly Mandarin, Cantonese, Hindi, and Vietnamese. The author makes a plea for overcoming a multilingual bias on the part of monolingual (English-speaking Australians). A multilingual venue is indeed an opportunity for learning languages on the part of monolinguals. Very important is his wish that Australia develop into "a society of multiple connectedness, not assimilation (my emphasis), not even just two way integration but connecting all sections of our society in an inclusive way" (p. 8). Observe that Clyne is not advocating "assimilation", for the problem with some bilingual programs in the USA and Canada is the attempt to have immigrants lose their native tongues and become monolingual in English. Assimilationalist language teaching policies are indeed the death knell of bilingualism and plurilingualism in all the five inner circles.

Clyne is one of the few writers who cites and lauds those individuals who are bilingual or multilingual. The first is the former prime minister of Australia, Kevin Rudd, who broke protocol by speaking Mandarin (and not in English) to the Chinese and the second is Al Gasby former minister for Immigration and Ethnic Affairs who, according to Clyne, is trilingual. His stalwart stand for multilingualism in Australia is evident in his remarks:

The way you really achieve something internationally is through participation in the others' cultures and especially languages. And we can start at home for Australia is a multilingual society. (p. 4)

Very much in line with Clyne's view is the work of Thompson (2011, p.210) in Australia who deals with the preparation of teaching material for "transcultural communicative classroom activity" (TCCA). She includes for discussion in multilingual classrooms texts written by a cultural theorist (Edward Said), a celebrated pianist (Daniel Barenboim), and the president of a country (Barach Obama) and an indigenous Australian linguist (Jeanie Bell). Part of Bell's text spells out the injustice done to her people (apud, THOMPSON, 2011, p.211):

Both of my parents had lived on government settlements. The policy was that you rounded all the Aborigines up and put them in reserves. People were forced to speak English and forget their traditional languages and cultures. [...] People were made to believe that the only acceptable form of communication and lifestyle was the one that mirrored the white one. 
In the next sub-station, we look at the last inner circle country, the archipelago of New Zealand, a nation that is slowly and steadily becoming multilingual and multicultural.

\subsubsection{New Zealand or Aotearoa ${ }^{12}$}

Based on the literature consulted, New Zealand prides itself on its multilingual status. A government document prepared by the Human Rights Commission is designed to protect and promote language diversity in the country. Here are the words of the commission:

New Zealand has a particular responsibility under the Treaty of Waitangi and international law to protect and promote te reo Mäori as the indigenous language of New Zealand. It also has a special responsibility to protect and promote other languages that are indigenous to the New Zealand realm: Vagahau Niue, Gagana Tokelau, Cook Island Mäori, and New Zealand Sign Language. It has a regional responsibility as a Pacific nation to promote and protect other Pacific languages, particularly where significant proportions of their communities live in New Zealand.

The nation holds Te Reo Maori and New Zealand Sign Language as official languages. There is some controversy over whether the Maori language is increasing or decreasing; the fact that there is a relatively large number of speakers of the language in relation to the size of the country (Australia is a continent and both the USA and Canada are continental) may auger well for the survival of Maori. But the words of Rangi Mataamua ${ }^{13}$ are a bit discouraging for he confesses that "we really don't know how to make people use the language [Maori]. We have a lot of children going to Maori language schools but they seem to be coming away from the schools and speaking English". But on the other hand, via the internet, one can easily observe the presence of the language at many universities in the country. The fact that there exists a certain amount of interest in not (my emphasis) allowing the language to die can be observed in an article in the International Journal of Lexicography

${ }^{12}$ Aoteoroa is the Moari name for New Zealand. It is also the name of an overture for orchestra composed by the New Zealand born composer, Douglas Lilturn (1915-2001).

${ }^{13}$ Dr. Rangi Mataamua is a specialist in the Moari language at the University of Waikato, Hamilton, New Zealand. Television interview available at <, 2013. 
about the recently published Modern Maori Legal Dictionary (STEPHENS AND BOYCE, 2011).

The dilemma of the aboriginal populations in the other inner circle nations is that there are many indigenous language with relatively small number of speakers-indeed a problem for language maintenance.

As in the case of the other inner circle countries, the vast majority of the speakers are monolingual speakers of English. Yet the New Zealand Human Rights Commission points to the presence of Asian and Pacific language communities that represent "... nearly a third of the population". In the document, one notes a geopolitical stance for the country is located in the Pacific region of the world, close to Asia and the Pacific islands. The study of Asian languages (Mandarin, Cantonese, Hindi) would contribute to opening markets and cultural interaction for New Zealand. One positive action for the development of multilingualism and multiculturalism in New Zealand is the existence of "community language broadcasting in Maori and Pacific languages". Not all countries permit radio or television programming in different languages.

One can say that at least there is a discourse in favor of multilingualism in New Zealand based on the words of the Human Rights Commission: " Promote positive public attitudes to language diversity and increase the number of people learning languages".

Table 5 shows the number of speakers of ten different languages in the country.

\section{TABLE 5}

Ranking of the ten most spoken languages spoken in New Zealand, excluding English

\begin{tabular}{lc}
\hline Language & Number of Speakers \\
\hline Maori & 157,110 \\
Sino-Tibetan & 109,027 \\
French & 53,752 \\
Hindi & 44,559 \\
German & 37,509 \\
Dutch & 26,982 \\
Korean & 26,967 \\
Afrikaans & 21,123 \\
Japanese & 20,883 \\
\hline
\end{tabular}

Source: StatisticsNewZealand/tatauranga aotearoa. Available at <www.stats.gov.nz/census2006HomePage> . Acessed May31, 2013. 
Table 5 points to language spread in New Zealand. Moari, although endangered, is the first ranking language (after English) that serves as a symbol of New Zealand identity. The Sino-Tibetan groups include Mandarin, Cantonese, Haka, and other languages. No doubt, with increasing immigration, other languages spoken in Asia (Korean, Japanese, and Hindi) will increase their respective number of speakers.

Having looked at the six inner circle nations, we will weave the various threads of thought together to present some concluding remarks in Section 5 below.

\section{Conclusion: What looking beneath the three circles has brought to the surface}

\section{Grand narratives: Writing histories of nations and hiding what really happened.}

Nation-states have their historians and often they extol the heroes of the homeland, glorifying the nation and the contributions of its people, particularly those who are deemed to be "mainstream" that is, those of Anglo-Saxon (British) ancestry and not Africans or Indians. Schlesinger's and Huntington's narratives erase the violence that occurred in the former "British colonies", in Canada, as well as in the antipodes. Looking beneath the three-circles model uncovers a story of violence that points to the inhumanity of human beings to their fellow human beings. The presence and participation of Afro-Americans, Latinos, and women of all ethnic backgrounds in the American Revolution are not always recognized in history texts. It will no doubt be difficult or practically impossible to change monolingual English speakers' mindsets about present-day multilingualism and multiculturalism if textbooks in the teaching of American, Canadian, and Australian history(ies) are not rewritten. ${ }^{14}$ To be sure, those books are written in English but they tend to ignore language, other language(s) and culture(s). A critical revision of history, therefore, is essential at the present time

\footnotetext{
${ }^{14}$ Trimbur (2008, p. 163) quotes Fishman (In: Marckwardt, 1968) who points to the presence of "ancestral languages" that were heard and spoken in American homes in the 19th and 20th centuries and not erased by the growth of English. He remarks that histories of American Education do not refer to underlying linguistic diversity in the country.
} 
in order to open the borders of the mind to the reality of a globalized twentyfirst century world characterized by migrations, as well as linguistic, ethnic, and religious diversity. The imagined communities of the inner circles nations have to be re-imagined, taking into consideration the reality of multicultural and multi-linguistic diversities.

\section{The three circles: coming together as one}

Based on the remarks presented in the preceding sections, it would appear that the inner circle nations are becoming more and more similar to both the outer circle and expanding circles. All the circles have immigrants due to diasporas and movement of peoples from one place to another. In addition to newcomers, temporary workers, and sojourners, there are a number of people who had roots in inner circle countries at the time of "discovery" and subsequent colonization. In Brazil, one can find Haitians and Koreans, in Singapore, Indians, Malays, Chinese, and people from the West. People are on the move for many reasons, some quite tragic; languages are also mixing and people as well. In the inner circle countries we find the same pattern: Sikhs and Vietnamese in the USA, Portuguese and Brazilians in Montreal and Toronto, Chinese in Australia and New Zealand. The various groups take their culture with them, thus we can do capoeira in New York, eat somosas in Sydney, appreciate samba music in Vancouver. In a word, inner circles still have their "age of acquisition users" or L1 speakers (of different regional and social varieties), but there are many "others" in that circle who were never homogeneous to begin with. Indeed the older view of the inner circle being a stable "English as a Native Language" (ENL), of the outer circle being exclusively ESL (English as a Second Language) and not ENL, and the expanding circle being the sole domain of EFL (English as Foreign Language) no longer hold. The circles are becoming more and more blurred. Not all people are rooted for they have international or transnational identities.

\section{A deeper look at migration. An interdisciplinary field}

Not all monolingual L1 (age-of-acquisition speakers) in inner circle nations are aware of the difficulties of being an immigrant, of leaving one's home and family to try to build a new life in a alien culture. Not all inner circle monolingual speakers are cognizant that many of those who emigrated would have preferred to remain in their own homeland, but economic conditions 
and political strife made and still make staying home impossible. With regard to the USA and Canada, Gonzalez (2000, p. 192) observes that "... a catastrophic economic crisis in Latin America" forces, or in his words, "pushes immigrants to the United States" (and no doubt to other nations, inner, outer, or expanding). Studies on immigration tend to be "faceless" for there is a need for narratives on the part of immigrants (male, female, or other) in order for them to express their thoughts about learning English and their wish to maintain their L1 or not.

There is indeed a need for an interdisciplinary study of migration and the complexities of immigration. There is a vast literature in an area of knowledge called "Migration Studies". In a review (KRALY, 2001) of a text entitled Migration Theory: Talking Across Disciplines (see review in Brettel and Hollifield (Eds.). New York: Routledge, 2000), the reviewer states that the area “... cries out for an interdisciplinary approach." She lauds the text for the different articles are written from different disciplinary perspectives on migration and the author follows the title and does "talk across disciplines". Kraly (2001, p. 15) writes:

Each of the individual chapters provides a critical review of the theoretical and research literature within the respective social science disciplines represented in the volume: history, demography and population studies, sociology, anthropology, economics, political science and legal studies.

Applied linguistics has likewise been concerned with the study of bilingualism and the problems of immigrants in their new environments. Friedman (2010, p, 193), in an interdisciplinary study, is concerned with "language socialization" in schools in the USA and other nation-states that "socialize" immigrant students into an "exclusionary national identity" (p. 199). Her study shows that there exists, in many socialization programs, a conflict between the attempt, on one hand, to include or mold individuals into a sole identity (as monolingual English-speaking Canadians or Australians) and, on the other, to respect the right for cultural diversity and transnational identities. To balance these two conflicting stances is not an easy task.

\section{Rethinking bilingual education, assimilation, heritage language protection}

A result of the presence of cultural diversity and multilingualism tends to turn some schools, in inner circle nations, into not completely harmonious 
venues. Public and private schools are "... a site of struggle among competing ethnolinguistic and national groups (FREIDMAN, 2010, p. 193 apud LANGMAN (2012). ${ }^{15}$ In Canada, the cultural capital and globality underlying English causes immigrants who live in francophone areas of the country to request that their children study English and not French. Another problem is the fact that the rate of bilingualism among francophone speakers is higher than among Anglophones. Not all English-speaking people wish to become bilingual. The monolingual mindset that Clyne criticizes in Australia pervades all nations examined in this essay. In Britain, not all school districts are willing to pay for extended bilingual education, for there is a drive on the part of government for the assimilation and abandonment of ethnic languages. Not all immigrants want to give up their linguistic and cultural identity and even their children and their children's children in general may not want to lose their heritage language or sever ties with their respective countries of origin. With respect to the USA, the words of Gonzalez (2000, p. 225), a bilingual speaker of Spanish and English and author of A History of Latinos in America: Harvest of Empire, are indeed important for he states that his immersion course in English in the 1950s in New York City turned him and many of his generation into "skillful users of the English language". That experience led him to advocate "transitional" bilingual education; he makes it clear that he is not in favor of maintenance bilingual courses (Spanish dominant programs), for the children fail to master English. In short, mastering English does not mean that Spanish or another heritage language must be surrendered. Gonzalez (p. 227) and Clyne (2008, p. 6), respectively, in the case of the USA and Australia, call for their numerous Englishspeaking monolingual citizens to study other languages. Gonzalez is a graduate of New York City public schools and his thoughts about bilingual schools echo HLR's (2001) disillusionment with the multilingual and multicultural education in the United Kingdom. For Gonzalez, schools

... should be dissecting and analyzing the new hybrid culture trends that emerged in the twentieth century from the amalgamation and functions of Latino, Anglo and black arts. From Tex-Mex, bugaloo and mambo, to Latin jazz, reggae, rap, and hip-hop, these new musical genres are our best examples of cultural bridges.

${ }^{15}$ Langman, J. Mother tongue education versus bilingual education education: Shifting ideologies and policies in the Republic of Slovakia. International Journal of the Sociology of Language, v. 154, p. 47-64, 2012. 
The author's words point to a change from traditional bilingual education to language education that accepts cultural hybridity, interculturality, or multiculturality in classrooms.

We have pointed out that all the five counties were bilingual or multilingual before the spread of English set in motion a monolingual, racist, and essentialist view of nation-states. The history of English is linked to the word "empire", for it was the British and American empires that brought "others" (settlers, the persecuted, slaves, indentured servants, criminals, adventurers) from the four corners of the world who contributed to thwarting homogenization, to culturally enriching the life of the inner-circle spaces where they went. The sub-title of Gonzalez' book "Harvest of Empire" is telling, for it shows what has been reaped over the years. That harvest has been a bad one, but it can become a "good one" and can augur well for social justice if the different voices of those who arrived as immigrants are heard and not marginalized. The terrain for new "harvests" is where multilingualism and multiculturalism are viewed as the norm (multilingualism was and still is the norm in the outer and expanding circles), where the trials and tribulations of newcomers are received with sympathy and empathy, where "differences" (no matter what they are) are not a problem, and where "speaking in many tongues" is incorporated into mindsets of all citizens.

\section{References}

BAMGBOŞE, A. Torn between the norms: innovation in World Englishes. World Englishes. v. 17, n. 1, p. 1-14, 1998.

$\mathrm{BAO}, \mathrm{Z}$. Social Stigma and grammatical autonomy in nonnative varieties of English. Language in Society. v. 32, Issue 01. p. 23-46, 2003.

BELL, D. The Cult of the Nation in France: Inventing Nationalism 1680-1800. Cambridge, Mass.: Harvard University Press, 2001.

BONFIGLIO, T. P. Mother Tongues and Nations. Paris: De Gruyter Mouton, 2010.

BONFIGLIO, T. Race and the Rise of Standard American. Berlin: De Gruyter Mouton, 2002.

BRUTHIAUX, P. Squaring the circles: issues in modeling English worldwide. International Journal of Applied Linguistics. v. 13, n. 2, p.159-178, 2003.

BRYSON, B. Down Under. London: Black Swan, 2001.

CRAWFORD, J. Hold your tongue: Bilingualism and the politics of "English only". Reading, Mass.: Addison-Wesley Publishing Company, 1992. (James Crawford's Language Policy Website \& Emporium. <www.languagepolicy.net/archives/ HYTCHGhtm>. Accessed May 2, 2013. 
CLYNE, M. Australia's unrecognized resources boom-the languages for Australia's future. First Annual Language and Society Lecture, Monash University, 2008. [www. Arts.monash.edu.au/language-and-society/languagefor-australias-future-php], accessed

D'SOUZA, J. Indian English: Some Myths, Some Realities. English World-Wide. v. 16, n. 1, p. 91-105, 1997.

DOUZET, F. O pesadelo hispânico de Samuel Huntington (p. 33-55). In: LACOSTE, Y. and RAJAGOPALAN, K. (Eds.) A Geopolitica do Inglês [The geopolitics of English]. São Paulo: Parábola Editorial, 2005.

ECKL, J. and WEBER, R. North-South? Pitfalls of Dividing the world by words. Third World Quarterly. v. 28, Issue 1, p. 3-23, 2007.

FISHMAN, J. The Depth and Breadth of English in the United States. In: MARCKWARDT, A. H. (Ed.) Language and Language Learning. Urbana, Ill.: National Council for the Teaching of English, 1968.

FOUCAULT, M. Discipline and Punish: The Birth of the Prison. New York: Vintage Books, 1979.

FRIEDMAN, D.A. Becoming National: Classroom Language Socialization and Political Identities in the Age of Globalization. Annual Review of Applied Linguistics, v. 30. p.193-210, 2010.

GONZALEZ, J. Harvest of Empire: A History of Latinos in America. New York: Penguin Books. 2001.

GOSS, J. Postcolonialism: subverting whose empire? Third World Quarterly. v. 17, Issue 2, 1996. p. 239- 250.

GUILLÉN, C. IS Globalization Civilizing, Destructive or Feeble? A Critique of Five Key Debates in the Social Science Literature. Annual Review of Sociology. v. 27, p. 235-260, 2001.

HARRIS, R, LEUNG, C. RAMPTON, B. Globalization, Diaspora and Language Education in England. In: Working Papers in Urban Language and Literacies. London: King's College, 2001. www.kcl.ac.uk/sspp/departments/education/workingpapers/ 17 pdf.

HENDRICKSON, R. American Talk: The Words and Ways of American Dialects. New York: Penguin, 1986.

HONEY, J. Language is Power. The Story of Standard English and its Enemies. London: Faber \& Faber, 1997.

HUMAN RIGHTS COMMISSION. Languages in Aotearoa New Zealand. Available at www.hrc.co.nz/hrc_new/hrc/cms/files/documents/21-May-2009_ 15-42-34_Statementonlanguagepolicy.html>. Accessed: January 10, 2014. 
HUNTINGTON, S. The Hispanic Challenge. Foreign Policy, July 10, 2010. Available at www.foreignpolicy.com/articles/2004/03/01/the_hispanic_ challenge\#ssthash.GlAa1AP4.dpbs>. Accessed January 10, 2014.

INNES, E. J. The social, economic \& political reasons for the decline of Gaelic in Scotland. 1993. Available at <www.scotishhistory.com/articles/highlands/ gaelic/gaelic_page2.html>. Accessed May 13, 2013.

KRALY, E.P. Review of Brettell, C.B \& Hollifield, J.F. (Eds.) Migration Theory: Talking Across Disciplines. New York: Routledge, 2000. In: Journal of Political Ecology. v. 8, n. 4, 2001. Available at <jpe.library.arizona.edu/Volume8/ volume8_4htlm>. Accessed June 16, 2013.

JEANJEAN, H. Language(s) and Identity(ies) in French Society. Itha do Desterro. n. 50, p. 73-98, (January-June), 2006. Available at <https//periódicos. ufsc.br/index.php/desterro/articles/view/7261/6697>. Accessed: January 10, 2014.

JENKINS, J English as a Lingua Franca: Attitude and Identity. Oxford: Oxford University Press, 2007.

JOHNSON, R. W. Fragile Gains: Two Centuries of Canadian and United States Policy Toward Indians. Washington Law Review. v. 66, p. 643- 717, 1991. Available at <digital.law.washington.edu/dspace-law/handle/1773.1/9>. Accessed: January 10, 2014.

KACHRU, B. B. The Other Tongue. English Across Cultures. Urbana, Ill. University of Illinois Press, 1982.

KACHRU, B. B. Standards, codification, and sociolinguistic realism: The English language in the outer circle. In: Quirk, R. and H. Widdowson, (eds.) English in the World: Teaching and Learning the language and the literature. Cambridge: Cambridge University Press, 1985.

KACHRU, B.B. The alchemy of English: The spread, function, and models in nonnative English. Oxford: Oxford University Press/Illini Press, 1986.

KACHRU, B.B. World English: Agony and Ecstasy. Journal of Aesthetic Education. v. 30, n. 2, p. 135-155, 1996.

KACHRU, B. B. Liberation Linguistics and the Quirk Concern. In: SEIDLHOFER, B. (Ed.) Controversies in Applied Linguistics. Oxford: Oxford University Press, 2003, p. 19-33.

LACOSTE, Y. \& RAJAGOPALAN, K. (Eds.) A Geopolitica do Inglês. [The Geopolitics of English]. São Paulo: Parábola Editorial, 2005.

LEE, E. and NORTON, B. The English Language, multilingualism, and the politics of location. International Journal of Bilingual Education and Bilingualism. 
v. 12, n. 3, p. 277-290, 2000.

LIPPI-GREEN, R. Accent, standard language ideology, and discriminatory pretext in the courts. Language in Society. v. 23, Issue 02, p. 163-198, 1994.

MARCKWARDT, A. H. (Ed.) Language and Language Learning. Urbana, Ill.: National Council for the Teaching of English, 1968.

MCCARTHY, C., CRICCHLOW, W., DIMITRIATIS, G. \& DOLBY, N. (Eds.), Race, Identity and Representation in Education. London: Routledge, 2005.

MEYERHOFF, T. Multiculturalism and Language Rights in Canada: Problems and Prospects for Equality and Unity. American University International Law Review. V. 9, Issue 3, p. 913-1013, 1994.

O CATHAIL, S. The Politics of the Irish Language under the English and British Governments. PDF. Barra Ó Donnabháin Symposium 2007. New York: Gluksman Ireland House, New Yotk University, 2007. Available at <irelandhouse.fas.nyu.edu/ pge/odonnabhainsymposium>. Accessed June 6, 2013.

PARK, J. S-Y and L. WEE. The Three Circles Redux: A Market-Theoretic Perspective on World English. Applied Linguistics. v.30, n.3, p.389-406, 2009. PENNYCOOK, A. The Cultural Politics of English as an International Language. London: Longman Group Limited,1994.

PENNYCOOK, A. Review of Language and Politics in the United States and Canada: Myths and Realties. (eds.) T. Ricento and B. Burnaby. Mahwah, N.J.: Lawrence Erlbaum Associates, 1998. In: Language and Education. v. 15, n.1, p. 71-76, 2001.

PHILLIPSON, R. Linguicism: Structures and ideologies in linguistic imperialism (p. 339-358). In: Stutnabb-Kangas, T and Cummins, J. (Eds.) Minority education: From same to struggle. Clevedon, UK: Multilingual Matters, 1988.

PHILLIPSON, R. Linguistic Imperialism. Oxford University Press, 1992.

PHILLIPSON, R. English, a cuckoo in the European higher education nest of languages? European Journal of English Studies. v. 10, n. 1, p. 13-22, 2006.

PILGER, J. A Secret Country: The Hidden Australia. New York: Alfred A. Knopf, 1991.

PUNG, C.S. Beyond the three circle model: a new model for World English. [scholarbank. s.edu/bitstream/handle/10635/16502/CheeSP

pdf? Sequence=1999]. Accessed March 2013. MA thesis National University of Singapore, 2009.

QUIRK, R. Language Varieties and standard language. In: SEIDLHOFER, B., 
(Ed.). Controversies in Applied Linguistics. Oxford: Oxford University Press, 2003, p. 9-19.

ROSENBERG, M. The number of countries in the world. geography.about. com/cs/countries/a/numbercountries.htm. 2012. accessed April 30, 2013.

SAID, E. Between two cultures. In: Viswanathan, G. (Ed.), Power, politics and culture:; Interviews with Edward Said (p. 233-247), New York: Pantheon, 2001. SCHMITZ, J. R. Review of Bill Piatt In: Only English?: Law and Language Polity in the United States. Albuquerque: The University of New Mexico Press, 1990. In: Revista de Letras (Campinas, S.P.) v. 12, n. 2, 1993.

SCHMITZ, J. R. Review of A Geopolitica do Inglês [The Geopolitics of English]. LACOSTE, Y. ; RAJAGOPALAN, K. (Eds.). São Paulo. Parábola Editorial, 2005. In: Signótica, v. 22, n. 2, p. 495-513, 2010.

SCHMITZ, J. R. On the notions 'native'/ 'nonnative': a dangerous dichotomy for World Englishes. Rask (Institute of Language and Communication, University of Southern Denmark), v. 23, p.. 3-26, 2006, reprinted from Signótica (with permission), v. 21, n. 2, p. 341-363, 2009.

SEIDLHOFER, B; (Ed.). Controversies in Applied Linguistics. Oxford: Oxford University Press, 2003, p. 9-19.

SEIDLHOHER, B. Understanding English as a Lingua Franca. Oxford: Oxford University Press, 2011, 240p.

SCHLESINGER, A. The Disuniting of America: Reflections on a Multicultural Society. New York: W.W. Norton, 1992.

SINGH, R. New/non-native Englishes revisited. A reply to my colleagues. Journal of Pragmatics. v. 24, Issue 3, p. 323-333, 1995.

STEPHENS, M. and BOYCE, M. Finding a balance. Customary Legal Terms in a Modern Maori Legal Dictionary. International Journal of Lexicography. v. 24, n. 4, p. 432-472, 2011.

TAN, C. English or Singlish? The Syntactic Influence of Chinese and Malay on the Learning of English in Singapore. Journal of Language and Learning. v 3, n. 1, p. 156-179, 2005.

THOMPSON, C. H. A dialogic approach to the design of a transcultural communication classroom activity in multilingual learners. Language, Culture and Curriculum. v. 24, Issue 3 p. 207-220, 2011.

TUCKER, G. Richard. Multilingualism and Language Contact: An Introduction. Annual Review of Applied Linguistics. v.17, 1997. p. 3-10. 
TRIMBUR, J. The Dartmouth Conference and the Geohistory of the Native Speaker. College English. v. 71, n. 2, p. 142-169, 2008.

WALES HISTORY BBC CYMRU/WALES. [www.bbc.co.uk/wales/history/ sites/themes/society/language_education,shtml]. Accessed June, 20.2013.

WALICEK, D. Review of Thomas Paul Bonfiglio, Race and the Rise of Standard American. Berlin: Mouton de Gruyter, 2002. In:Linguist List 14. 1653 Review: Socioling/Dialectology: Bonfiglio (2002), p. 1-6, 2003. Available at <linguistlist.org/ issues/14/14/1653.html>. Accessed August 5, 2013.

WARD, I.C. The Phonetics of English. Cambridge: Heffer, 1956.

YANO, Y, World Englishes in 2000 and beyond. World Englishes. v. 20, n. 2, p.119-131, 2001.

Recebido em 29/06/2013. Aprovado em 27/11/2013. 